\title{
On the Cultural Basis of Core Values of the U.S. Soldiers
}

\author{
Fang Hua ${ }^{1 *}$, Liu Wenjuan ${ }^{2}$, Du Keke ${ }^{3}$, Wei Ting ${ }^{4}$, Wang $\mathrm{Zi}^{5}$, Zhang Mengqi ${ }^{6}$ \\ ${ }^{123456}$ The work units of the authors are the College of Information and Communication, National University of Defense
}

Technology

*Corresponding author: hwhada12@sina.com

\begin{abstract}
soldiers' core values centrally reflect the cultural identity and value pursuit of the army members. It is the core of military culture construction. Any army is built on the social foundation of a country and nation. As an activity with an ideology, its construction of core values of soldiers is bound to be restricted and affected by the country, nation and army culture intrinsically and imperceptibly. Religious belief, social tradition, western traditional military ethics and military professional ethics constitute the cultural basis of the core values of the U.S. soldiers.
\end{abstract}

Keywords: U.S. army; core values of soldiers; cultural basis;

\section{INTRODUCTION}

Xi Jinping deeply points out that solid core values had their inherent roots, and the spiritual lifeline would be cut if the tradition and the root were abandoned.1As an ideology and value orientation, the core values of American soldiers are the product along with the development of the whole American society and historical culture of the army. They are deeply affected by American society, traditional religion, historical military ethics, occupational ethics, etc.

\section{RELIGIOUS CULTURE IS THE CULTURAL ROOT OF THE CORE VALUES OF AMERICAN SOLDIERS}

Marx Weber once said that the United States was the most secular but most religious country. Religion plays an important role in the formation of core values in American society. In the 1830 s, when French political ideologist Tocqueville visited the United States, he said that in France, the spirit of religion and the spirit of freedom always seemed to go against each other; however, in the United States, he found that they were closely related, and ruled the same country together. 2

It is a tradition in the United States to foster core values with religion. From the early immigrants to previous presidents, senior government officials and every ordinary people, the guiding function of religion in the construction of core values has always been highlighted. Today, religion still plays an education role of a strong core value in American life. In the end of the 20th century, there were more and more single-parent families in American society, and the divorce rate and crime rate were high. Many Americans started to deny the existence of absolute moral principles and values and yearned for a more meaningful religious life. Religious emotions play an important role in affecting politics and culture again. Since 1988, there has been a significant increase in the number of articles on values and religious culture in the journals of two major parties. For example, the Clinton Administration ever made an explicit rule on religion that school leaders might not prevent students from discussing religion or praying in the school; in the federal workplace, the government respected the expression of individual federal employees to religious beliefs and Christians could put Bibles on their desks. Some people comment that it is the biggest treasure Clinton left behind that he took the lead to reduce prejudice of many people in the Democratic Party and liberals against religion for decades. 3

In such a social context, since the establishment of the U.S. army, religion has been closely associated with it, and it has deeply affected the thinking, emotions and actions of officers and soldiers. At present, the number of officers and soldiers who believe in religion in the U.S. army is more than $98 \%$. Almost everyone has a religious classic book. There are also various churches in the camp for officers and soldiers to carry out religious activities, even in wartime. Due to the religious belief demand of officers and soldiers, the relatively mature and perfect army chaplain system has been established in the U.S. army, and religion has also become a powerful tool for the military to strengthen the spiritual control of the army and the construction of the core values of soldiers.

Religious moral traces can be seen anywhere in the core values of the U.S. soldiers. Take Christianity for example. The Christian ethical norm based on the Bible has been playing a dominating role in American values and moral standards. The core values of American soldiers can be roughly divided into two parts, among which one is the occupational ethic requirements, and the other is personal ethic requirement. The "loyalty" thought throughout occupational ethic requirement directly corresponds to the 
most important Faith of Christian doctrines(love, belief and loyalty to the Lord). And "honesty, bravery and protecting the country" in personal ethic requirements are naturally the derivatives of the belief of "fighting for God". Officers and soldiers may not express their faith to religion and their loyalty to God until they strive to achieve these.

\section{SOCIAL TRADITIONAL CULTURE IS THE SOIL OF CORE VALUES OF THE U.S. SOLDIERS}

Individualism, pragmatism and liberalism are the distinctive features of American contemporary social culture. As a result, "individualism, freedom, equality, democracy and the rule of law" become the core values in the United States.4These mainstream culture and values are also accumulated in the ideology of individual soldiers and become the basis and guidance of core values of soldiers. The purpose of the existence of the army is to maintain the social realization of these core values. Therefore, no matter how political party of U.S. bourgeois take turns in power, the U.S. army has always been firmly controlled by the bourgeoisie and become the backbone of safeguarding national honor and interests.

Individualism has a profound impact on American values. Robert N. Bellah, an American sociologist, said that individualism was the most profound national feature of Americans and the core of American culture. 5Generally speaking, it contains three meanings: (1) equal opportunity, (2) independence and respect for others, (3) respect for others and personality. The value orientation of individualism is obviously reflected in the content construction of the core values of the soldiers, e.g. high light the rendering of individualistic heroism, emphasize that the victory of battles and the successful completion of tasks are inseparable from the individual fighting spirit and innovation awareness of soldiers. The U.S. army believes that the value of individual life is extremely precious, and a sound life is the basis of life. Therefore, the U.S. military allows soldiers to surrender as captives in special cases, so that their lives can be saved. In the official media, the soldiers who are forced to surrender are also national heroes and worth of respecting by the mass. For the word loyalty in the values, the U.S. army believes that loyalty does not mean to show servility in front of the chief and no fear of sacrifice in the battlefield, but to maintain their own free will, make choices beneficial to the army and the country and do things to safeguard the national interests. That is to say, loyalty includes individual independent judgment and free choice.

Pragmatism is the mainstream of American social culture. In the American spirit, "focusing on effectiveness and action and advocating progress" fully reflect the value orientation of pragmatism, and affect the development of American society. The theoretical essence of pragmatism can be summarized as follows: judge the advantages and disadvantages with the final effect, survive by relying on the practical action, and strive for development with positive progress. Even if sometimes methods and means are unreasonable and even immoral, they can be allowed and adopted as long as they can achieve the best results and benefits. During cultivation of core values, it is common for the U.S. army to not tell the truth, become capricious and use unscrupulous tactics. For example, in Vietnam, the U.S. army used money and pornographic incentives and other means publicly to encourage soldiers to fight for American values.

Liberalism is the foundation of American social culture. Since Patrick Henry said the famous slogan which is "give me liberty or give me death", the value of liberalism has gradually become deeply rooted among people. Freedom is recognized by law in the Declaration of Independence, United States Constitution and Bill of Rights. Liberalism not only determines the basic principles and national defense policies of the United States, but also profoundly affects the establishment and cultivation of the core values of the U.S. soldiers. For example, the definition of "courage" in the core values of the U.S. navy is as follows."Even in adversity or in front of temptation, the strong spiritual support is still provided for doing the right thing with the greatest confidence and determination." This also corresponds to the meaning of "freedom" interpreted in the core values of American society that individuals act and think freely according to their own will as long as they do not violate the freedom and benefits of others without any reason. The U.S. army has always made every effort to promote and protect "freedom and democracy", and the protection of independence, development and prosperity of all free countries in the world is the main purpose and important responsibility of cultivating the core values of U.S. soldiers.

\section{WESTERN TRADITIONAL MILITARY ETHIC CULTURE IS THE MAIN REASON FOR THE FORMATION OF CORE VALUES OF SOLDIERS}

Although the United States has been established for 200 years, its culture has almost completely inherited the western civilization, and the formation of the core values of American soldiers is no exception. It is developed and established during the process of inheriting the western traditional military culture, and it is deeply affected in content construction, cultivation methods, foundation construction, etc. Through the complex and long battle and military activities, the western traditional military culture can be summarized as individual values of "worshiping heroes", war values of "advocating wars and fighting" and military values of "hegemonism and expansion".

The core values of American soldiers inherit the individual values of hero worship. For thousands of years, the western civilization is full of the worship of individualistic heroism. In ancient Greece, because of frequent wars, the values of advocating heroes came into being, which is the beginning of western traditional military culture. The Homer Epic tells people poetically that war is a noble and 
great cause and it is the main way for ordinary people to become heroes with great honors. Advocating heroes and striving to become heroes through war become the mainstream value pursuit of ancient western society. In the western traditional moral culture, the criteria for selecting soldiers are courage, strength and other elements first of all. Clausewitz stressed that courage was the primary quality a soldier should have. Fuller concluded that the history of Europe was born out of such heroism. Such a value orientation also makes the contemporary US army have a unique historical feeling of honor. In the navy, warships and submarines named after heroes can be seen anywhere. The navy carves the names and birthplaces of the best officers and soldiers for military service on the deck of warships every year, which makes officers and soldiers feel extremely honored. The heroism of daring to take risks is also a distinctive feature of American air force values. They strive to "pursue excellence" and believe that joining the air force is to accept adventure without fear of various risks and challenges. Instructed by the values which advocate adventure and emphasize individual success, a large number of "ace pilots" emerge in the air force.

The core values of American soldiers are the development of the war values of "advocating war and fighting". The western traditional military culture knows and understands battles from the perspective of human nature in pursuit of desire and it believes that the battle itself conforms to human nature. It basically affirms and praises battles, and believes that the best way to solve conflicts is to resort to battles. The war value of "advocating war and fighting" emphasizes that "interest" is the only standard to consider the war value. In terms of the dominant tendency of battles, the basic position of "gaining interests through war" is adhered to and military force is used as the primary principle to solve conflicts and seek national interests. The United States has been founded for more than 200 years and it has started overseas wars for more than 200 times. Afterwards, the United States became more prosperous and powerful. For the United States, the war seems to be a reward to a certain extent. Affected by this view of interests, the U.S. army also pays full attention to the material interests of officers and soldiers in the cultivation of core values of soldiers in U.S. army. For example, the basic salary of officers is higher than local level, and the salary of soldiers is sufficient to support their family. Increasing the salary is the common way for the U.S. army to ensure the source of troops and boost morale, so many people believe that they can stay for money and leave in case of no gains. In the army, it is filled with employment ideas and money relations.

The core values of U.S. soldiers are the promotion of hegemonic expansion in the army values. The main theme of western traditional military culture is to advocate force and power, and the value of "hegemonic expansion" which is centered on material gains and seeks expansion always plays the dominant role. Solon once concluded that a civilization could become stronger because it bred strong imperial ideal and desire to conquest insides, and once these disappeared, the whole civilization would dry up and die. In the history of the establishment of the United States, it can be found that plunder, conquest and colonial expansion are the paving stones for the development of American civilization. As a violent tool for the United States to conquer the world and maintain its hegemonic status, the core values of the U.S. army reflect "hegemonic expansion" anywhere. The former U.S. army was the Continental Army born in the war of independence. At the beginning, its mission was to serve and follow the mission of protecting "independence, freedom and democracy" of the United States. The U.S. army always regards itself as the most loyal servant of the nation. Along with the continuous strategic guidance of overseas expansion, the U.S. navy quickly moved to the front of history and became a vanguard. It actively runs in the front line for economic and political interests and fully reflects the core values of "honor, courage and dedication". In the 20th century, along with the development of the theory of the air control, the construction and use of air force has drawn more and more importance day by day. Selfless dedication and pursuit of excellence are the high condensation of its core values. The expression of each service shows a distinct value orientation, which constitutes the core value system of military services with American features. In this system, the internal implications of hegemony and offensive strategies are fully reflected, the core values of various services of the U.S. army are infused with the core of "safeguarding the national constitution", "Darwinism", etc. In this way, it fights for the expansion of national interests all over the world with the legal pretext.

\section{MILITARY OCCUPATIONAL ETHIC CULTURE IS THE INTERNAL SUPPORT OF THE CORE VALUES OF U.S. SOLDIERS}

The occupational ethic culture of the U.S. army is also commonly called military ethical and moral culture, which includes many categories such as soldiers' core values, war standards and judgments and battlefield ethical and moral codes. It is an organic entirety with clear purpose, complete system and close relationship. It specifically answers why soldiers fight and how they fight. It is an important spiritual support in soldiers' core values.

American army occupational ethic culture is deeply affected by western professionalism. In the 15th century, Martin Luther firstly proposed that the job was a type of bounden duty, and it was a mission delivered by God, rather than a kind of behavior or business that individuals did to meet their survival. In this view, the job is regarded as the attachment of life significance and value, and career is the most valuable part of life. Under the influence of this idea, according to the features of their professions and departments, all walks of life and departments in the United States have successively formulated regulations suitable for their staff in their institution, such as the Code of Conduct for Personnel in the United States Department of Defense, the Code of Occupational Conduct, etc. They 
are featured by strong pertinence, detailed content and general binding force on staff. The history of military occupation in the west is not very long, but the United States and other western countries still generally recognize the professionalism and particularity of military occupation, and recognize that the moral requirement of professional soldiers is far higher than that of other occupations.

Along with the development of the U.S. army, the occupational ethic culture of the U.S. army is constantly enriched and improved. At the beginning of independence, militiamen were encouraged with values of freedom, democracy and equality. Today, it regulates the behavior of the whole army with occupational military ethics and morality and cultivates officers and soldiers the moral outlook of loving their jobs and devoting themselves to them, as well as sacrifice and dedication. The content of American professional ethics and culture has gradually developed towards institutionalization and systematization, the main form of which is to issue rules and regulations or codes, creeds, etc. For example, the U.S. army issued the Doctrines of Sergeant, Doctrines of Soldiers, Doctrines of Civilian Personnel of U.S. Army, etc. which have clearly stated who the officers and soldiers should uphold, what they believed, and what responsibilities they should take and other required codes. Uniform Code of Military Justice, Military Court Manual, the U.S. Naval Administration Ordinance, etc. are the legal basis of punishing the soldiers who violate against occupational ethics.

The core values of American soldiers are the centralized expression of military occupational ethics and culture. Throughout the content of the core values of the soldiers of all services of the U.S. army, although they are expressed differently, their essence is highly consistent, and all of them emphasize honor, responsibility, loyalty, dedication, respect and courage. These are the core concepts of American occupational ethics culture. First of all, advocating honor is the soul of military occupational ethics culture. The U.S. army believes that the sense of honor can encourage officers and soldiers to place their values above their personal interests and career development, and to fulfil or excessively fulfill their legal obligations and moral and obligations. The second is the sense of responsibility. The U.S. army believes that officers, as a special occupation, shall take the initiative in performing their duties and take full responsibility for their own and their subordinates' behaviours. They may not make individual contributions to the army until they have a high sense of responsibility. The third is absolute loyalty. The U.S. army believes that loyalty has different levels. Due to the differences in tasks, different services have different forms of loyalty. In the air force, service precedes soldiers themself. The form in the navy is "ship-crew-ego". Those who the army shall be loyal to are successively constitution, army, institution and soldier. The fourth is selfless dedication. The U.S. army believes that the source power of military fighting comes from the lofty ideal of transcending personal interests. Selfless dedication is the moral requirement that distinguishes soldiers from other occupations. The fifth is mutual respect. The U.S. army believes that officers shall take the initiative to understand others, consider their different cultural backgrounds, and show respect for them, which is also an occupational demand. The sixth is courage. The fighting spirit advocated by the U.S. army is mainly reflected by the understanding to the value of the U.S. army and the occupation attitude towards the mission. It is the cornerstone for the army to achieve victory. The U.S. army believes that courage can help officers and soldiers overcome fear, hunger and fatigue, and enhance their fighting capacity. U.S. army may not win the battle until the purpose is clear and the soldiers are brave. Therefore, the U.S. army has always regarded courage as an essential part of occupational spirit.

\section{CONCLUSION}

To sum up, the core values of U.S. military personnel are not born out of thin air, but based on their profound religious culture, social traditional culture with pragmatism, individualism and liberalism as the core, unique western traditional military ethics culture and mature military professional ethics culture. It is precisely because these cultural bases, which together constitute the core values of the U.S. military and the mainstream culture and value pursuit of the United States, are of the same quality, homology and orientation with the mainstream culture and value pursuit of the U.S. military, so as to ensure that the core values of the U.S. military can be deeply rooted in the hearts of the people and shine brilliantly, and provide an endless source of spiritual power for the generation of the combat effectiveness of the US military.

\section{REFERENCES}

[1] Xi Jinping: Making the influence of socialist core values pervasive as the air, Speech at the 13thCollective Learning of the Political Bureau of the Central Committee of the CPC, Xinhuanet, April 25, 2014

[2] Tocqueville: Democracy in America (Volume I), commercial press, 1995 edition, Page: 385.

[3] Samuel Huntington: Who Are We? The Challenges to America's National Identity, Xinhua press, 2010 edition, page: 251 .

[4] Zhou Wenhua: Construction and Enlightenment of Core Values in the United States, Intellectual Property Press, 2014 edition, Page 1.

[5] Robert Bela: Habits of the Heart: Individualism and Commitment in American Life, Sanlian Bookstore, 1991 edition, Page 214 